\title{
Nutrients Formulation for Improving Production and Quality of Potato Minitubers Using Aeroponic System in Indonesia
}

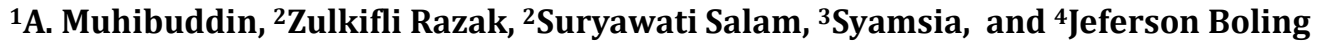 \\ 1,4 Department of Agrotechnology, Faculty of Agriculture, Bosowa University, Makassar 90231 South Sulawesi, Indonesia \\ 2 Department of Social Economic, Faculty of Agriculture, Bosowa University, Makassar 90231 South Sulawesi, Indonesia \\ 3 Department of Agrotechnology, Faculty of Agriculture, Muhammadyah University, Makassar 90221 South Sulawesi, Indonesia
}

Correspondence Author: A. Muhibuddin, Department of Agrotechnology, Faculty of Agriculture, Bosowa University, Makassar 90231 South Sulawesi, Indonesia

Received date: 12 August 2018, Accepted date: 10 December 2018, Online date: 25 December 2018

Copyright: (c) 2018 A. Muhibuddin et al., This is an open-access article distributed under the terms of the Creative Commons Attribution License, which permits unrestricted use, distribution, and reproduction in any medium, provided the original author and source are credited.

\begin{abstract}
One of effective strategies to speed up production of potato minitubers is tissue culture continuing with aeroponic system. This combination has several benefits, such as high productions, invulnerable to systemic plant diseases, independent on seasonal climates, and more continuous productions. The objective of this research was to determine the proper nutrients formulation on the aeroponic system for two different potato cultivars (atlantic and granola). This research used split plots design, the main plot was for potatoes (cultivar atlantic and granola), while the subplot was for nutrient formulation comprising four treatments: $\left.F_{1}=N_{\left(N_{3}-125:\right.} \mathbf{N H}_{4}{ }^{+} 25\right), P 20, K ~ 100, C a ~ 75$, Mg 50, S 25, Fe 2.0, Cu 0.1, Mo 0.05, Mn 0.5, Zn 0.1 and B 0.2 mg/l; $F_{2}=N\left(N_{3}-145: \mathrm{NH}_{4}+30\right), P$ 40, K 150, Ca 100, $\mathrm{Mg}$ 60, $\mathrm{S} 50, \mathrm{Fe} 4.0$, Cu 0.2, Mo 0.10, Mn 1.0, $\mathrm{Zn} 0.2$ and B $0.4 \mathrm{mg} / \mathrm{l} ; \mathrm{F}_{3}=\mathrm{N}\left(\mathrm{NO}_{3}-165: \mathrm{NH}_{4}{ }^{+} 35\right), \mathrm{P} 60, \mathrm{~K} \mathrm{200}, \mathrm{Ca} \mathrm{125,} \mathrm{Mg} 70, \mathrm{~S}$ 75, Fe 6.0, Cu 0.3, Mo 0.15, Mn 1.5, Zn 0.3 and B $0.6 \mathrm{mg} / \mathrm{L}$; and $\mathrm{F}_{4}=\mathrm{N}\left(\mathrm{NO}_{3} \cdot 185: \mathrm{NH}_{4}{ }^{+} 40\right), \mathrm{P} \mathrm{80}, \mathrm{K} 250, \mathrm{Ca} 150, \mathrm{Mg} \mathrm{80}, \mathrm{S}$ 100, Fe 8.0, Cu 0.4, Mo 0.20 , Mn $2.0, \mathrm{Zn} 0.4$ and $B 0.8 \mathrm{mg} / \mathrm{l}$. The results showed that treatment $F_{4}$ gave better effects than treatment $F_{1}$, however it did not show significant effect compared to treatment $F_{2}$ and $F_{3}$ on increasing production (number of tubers, tubers weight and tubers diameter) and quality (carbohydrate content of tubers, tubers hardness, and water content of tubers) for both cultivar atlantic and granola. Cultivar atlantic was better than cultivar granola on the parameter of tubers production and quality.
\end{abstract}

Key words: Potato minitubers, Aeroponic, Nutrients formulation, Tissue-culture.

\section{INTRODUCTION}

Potato (Solanum tuberosum L.) is the most important non-grain food crop in the world [1], high economic values and able to be made various type of foods [2]. In addition, potato is more durable to store compared to other vegetables and are useful as therapeutic foods for diabetics [3]. The availability of potato seed in Indonesia is far from adequate, only $\pm 10 \%$ of the national needs of 120.000 tons/year (including imported ones), while the potato productivity is just \pm 12 of 40 ton/ha potentials [4]. In order to speed up the national potato production, innovative production technology is required to reduce the import of potato seed.

One of the production technologies developed in Indonesia is aeroponic system which produce potato minitubers (generation 0) [5]. The aeroponic system is the technique of growing crops by supplying nutrient solution to crop roots via abrogation [6]. The roots are hanging, then the solution is sprayed from the bottom through the sprinkler and the roots will absorb the nutrients [7],[8]. Aeroponic system has several benefits, such as high productions, invulnerable to systemic plant diseases, independent on seasonal climates, and enhanced continuous productions [9],[10],[11], [12]. In aeroponic system, the crops need water contained nutrients as a source of food, therefore the use of soil as a medium is not required [6],[13],[14].

Production and quality of potato tubers from aeroponic system may be affected by several factors, such as fertilizer composition, cultivars, condition of plant media, growing conditions [15],[16],[17]. First report on aeroponic system in potato particularly in Indonesia is reported by Sub [5], using a fertilizer formulation $\mathrm{N}\left(\mathrm{NO}_{3}^{-} 175: \mathrm{NH}_{4}^{+} 25\right), \mathrm{P} 75, \mathrm{~K} 200, \mathrm{Ca} 175, \mathrm{Mg} 75, \mathrm{~S} 125, \mathrm{Fe} 3.0, \mathrm{Cu} 0.1$, Mo 0.05, Mn 2.0, Zn 0.3 and B 0.7 mg/l with Electrical Conductivity (EC) = 2.7 $\mathrm{mS} / \mathrm{cm}$, which has been used in other vegetables vegetable. It produced around 27 tubers per plant which was considerably higher than the conventional system which merely produced 3-5 tubers per plant. Meanwhile, the research of aeroponic system conducted in Brazil [18], on potatoes showed that the concentration of $\mathrm{N} 198\left(7: 1 \mathrm{NO}_{3}{ }^{-}: \mathrm{NH}_{4}{ }^{+}\right), \mathrm{P} 39, \mathrm{~K} 183, \mathrm{Fe} 2.76, \mathrm{Mn} 0.97$ and $\mathrm{Cu} 0.02 \mathrm{mg} / \mathrm{l}$ resulted in the best growth and production. In Belgium [19], It reported that the concentration of $\mathrm{N} \mathrm{180,} \mathrm{P} \mathrm{40,} \mathrm{K} \mathrm{300,} \mathrm{Fe} \mathrm{3.0,} \mathrm{Mn} 1.0$ and Cu $0.1 \mathrm{mg} / \mathrm{l}$ was the best concentration of various cultivars of potato. The potato aeroponic technology in some African countries have been developed [20], and aeroponic technology in Peru produced over 100 tubers per plant [21]. potato.

The objective of this research was to determine the proper nutrient formulation on aeroponic system for minituber production atlantic and granola cultivars of

\section{MATERIALS AND METHODS}

This study started with the propagation of plantlets in the Tissue Culture Laboratory of Bantaeng District, South Sulawesi Province, Indonesia. The research was continued at the Horticulture Seed Center in Ulu Ere, Bantaeng District, located at altitudes 900 m above mean sea level (AMSL), lasted in 2016 - 2017 (four 
growing seasons). This research used split plots design, the main plot was for potato cultivars atlantic $\left(\mathrm{V}_{1}\right)$ and granola $\left(\mathrm{V}_{2}\right)$, while the subplot was for nutrient formulation comprising four treatments $\left(\mathrm{F}_{1}, \mathrm{~F}_{2}, \mathrm{~F}_{3}\right.$, and $\left.\mathrm{F}_{4}\right)$, the formulation compositions are shown on Table 1 .

There were two cultivars and four nutrient treatments in the experiment and replicated by three times. Data from the experiments was statistically analyzed using software SPSS version 16. The differences among treatments were compared using Least Significant Difference (LSD) test at 5\% probability level.

Table 1: Detail of Nutrient Formulations under Aeroponic System

\begin{tabular}{|c|c|c|c|c|c|c|c|c|c|c|c|c|c|}
\hline \multirow{3}{*}{ Treatments } & \multicolumn{13}{|c|}{ Macro and micro nutrients (mg/L) } \\
\hline & \multicolumn{2}{|c|}{$\mathbf{N}$} & \multirow{2}{*}{$\mathbf{P}$} & \multirow{2}{*}{ K } & \multirow{2}{*}{$\mathrm{Ca}$} & \multirow{2}{*}{ Mg } & \multirow{2}{*}{$\mathbf{S}$} & \multirow{2}{*}{$\mathrm{Fe}$} & \multirow{2}{*}{$\mathrm{Cu}$} & \multirow{2}{*}{ Mo } & \multirow{2}{*}{ Mn } & \multirow{2}{*}{$\mathbf{Z n}$} & \multirow{2}{*}{ B } \\
\hline & $\mathrm{NO}_{3}{ }^{-}$ & $\mathbf{N H}_{4}{ }^{+}$ & & & & & & & & & & & \\
\hline $\mathrm{F}_{1}$ & 125 & 25 & 20 & 100 & 75 & 50 & 25 & 2.0 & 0.1 & 0.05 & 0.5 & 0.1 & 0.2 \\
\hline$F_{2}$ & 145 & 30 & 40 & 150 & 100 & 60 & 50 & 4.0 & 0.2 & 0.10 & 1.0 & 0.2 & 0.4 \\
\hline $\mathrm{F}_{3}$ & 165 & 35 & 60 & 200 & 125 & 70 & 75 & 6.0 & 0.3 & 0.15 & 1.5 & 0.3 & 0.6 \\
\hline $\mathrm{F}_{4}$ & 185 & 40 & 80 & 250 & 150 & 80 & 100 & 8.0 & 0.4 & 0.20 & 2.0 & 0.4 & 0.8 \\
\hline
\end{tabular}

This research included some steps respectively: 1) Propagation of plantlets; 2) Acclimatization four weeks before being planted to the aeroponic media; 3 ) Preparation of planting medium in the aeroponic media: coconut husk was arranged flatly inside the aeroponic box in order to absorb nutrients which made the aeroponic box remaining wet. PVC pipes draining nutrient solution were connected to sprinklers. Styrofoam size of $(100 \times 75) \mathrm{cm}$ and $3 \mathrm{~cm}$ thick was hollowed with a diameter of $1.5 \mathrm{~cm}$ becoming the planting media of seed potatoes, and the distance between holes is $(25 \mathrm{x} 35) \mathrm{cm}$. Afterwards, The silver mulch was installed to cover styrofoam and aeroponic box. Irrigation canals connected to the nutrient reservoir will drain the solution to polyethylene pipes placed in a tub plant that has been plugged to sprinklers. In order to push and drain solution, a pump with high pressure (1.5-2.0 atmospheric pressure) was utilized; 4) Planting: planting potato seedlings was applied when the age of plant was 3 weeks or the number of leaves were 5-7 strands, and the seedlings height were about $15 \mathrm{~cm}$. The seedlings were planted on a styrofoam that have been prepared and placed on a surface of box. Planting was applied by wrapping the base of stem using rockwool to support the upright position of the crops. The stages of the research are shown on figure 1.

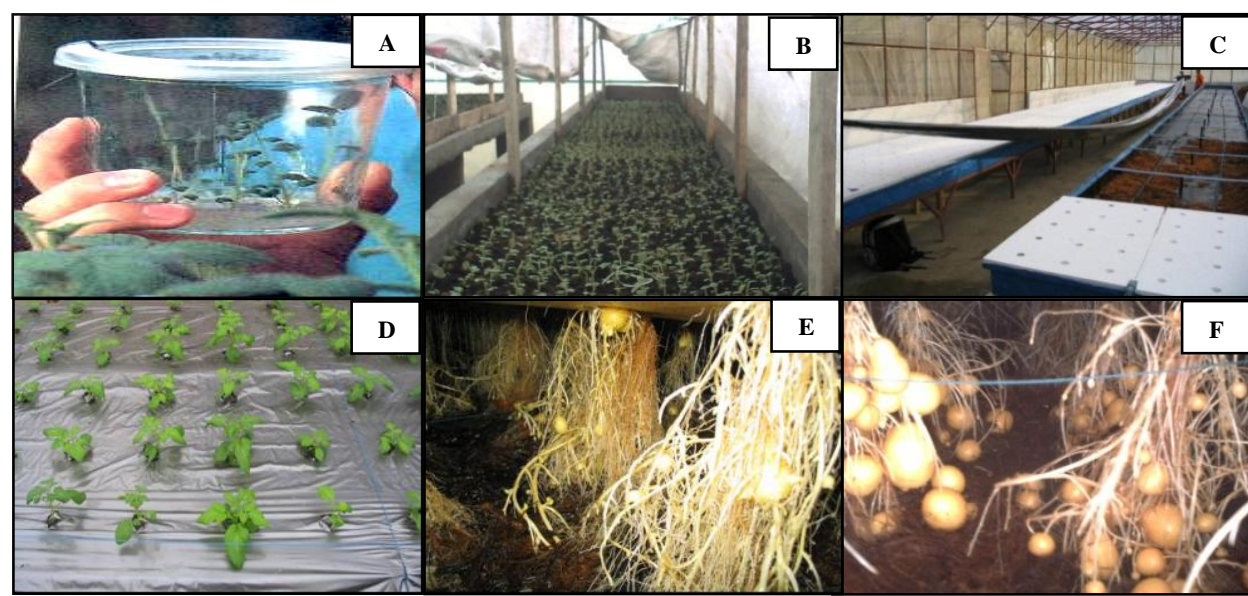

Fig 1: Propagation plantlets (A), Acclimatization (B), Preparation media aeroponics (C), Crop age two weeks after planting in the media aeroponics (D), potato Rooting System (E), and development of tubers (F).

\section{RESULTS AND DISCUSSION}

\section{Tubers Production}

Treatments on cultivar atlantic resulted in higher tubers weight and larger size of tubers per crop than on cultivar granola, however the number of tubers between those cultivars was not significantly different (Table 2). Treatment $\mathrm{F}_{4}$ had shown the best result on number of tubers, tubers weight and tubers diameter, even though there was no significant difference with treatment $\mathrm{F}_{2}$ and $\mathrm{F}_{3}$. Figure 2 shows that nutrients formulation had positive linear relationship with the number of tubers, tubers weight and tubers diameter on cultivar atlantic and granola, the equation of each parameter is shown on figure 2 (A, B and C).

Table 2: Average Number of Tubers, Tubers Weight, and Tubers Diameter on Nutrients Formulation

\begin{tabular}{|c|c|c|c|}
\hline Treatments & $\begin{array}{c}\text { Number of Tubers } \\
\text { (Nos) }\end{array}$ & $\begin{array}{c}\text { Tubers } \\
\text { Weight (g) }\end{array}$ & $\begin{array}{c}\text { Tubers } \\
\text { Diameter (cm) }\end{array}$ \\
\hline Cultivar & & & \\
\hline$V_{1}$ & 30.41 & $369.96^{\mathrm{a}}$ & $3.80^{\mathrm{a}}$ \\
\hline $\mathrm{V}_{2}$ & 29.27 & $343.24^{\mathrm{b}}$ & $3.64^{\mathrm{b}}$ \\
\hline Nutrients Formulation & & & \\
\hline F1 & $27.64^{\mathrm{c}}$ & $329.62^{\mathrm{c}}$ & $3.65^{\mathrm{b}}$ \\
\hline F2 & $29.42^{\mathrm{bc}}$ & $352.96^{\mathrm{b}}$ & $3.69^{\mathrm{ab}}$ \\
\hline F4 & $30.34^{\mathrm{ab}}$ & $365.68^{\mathrm{ab}}$ & $3.77^{\mathrm{a}}$ \\
\hline
\end{tabular}

Note: Values followed by the same letter indicated not significantly different according to LSD test at $5 \%$ test level. 

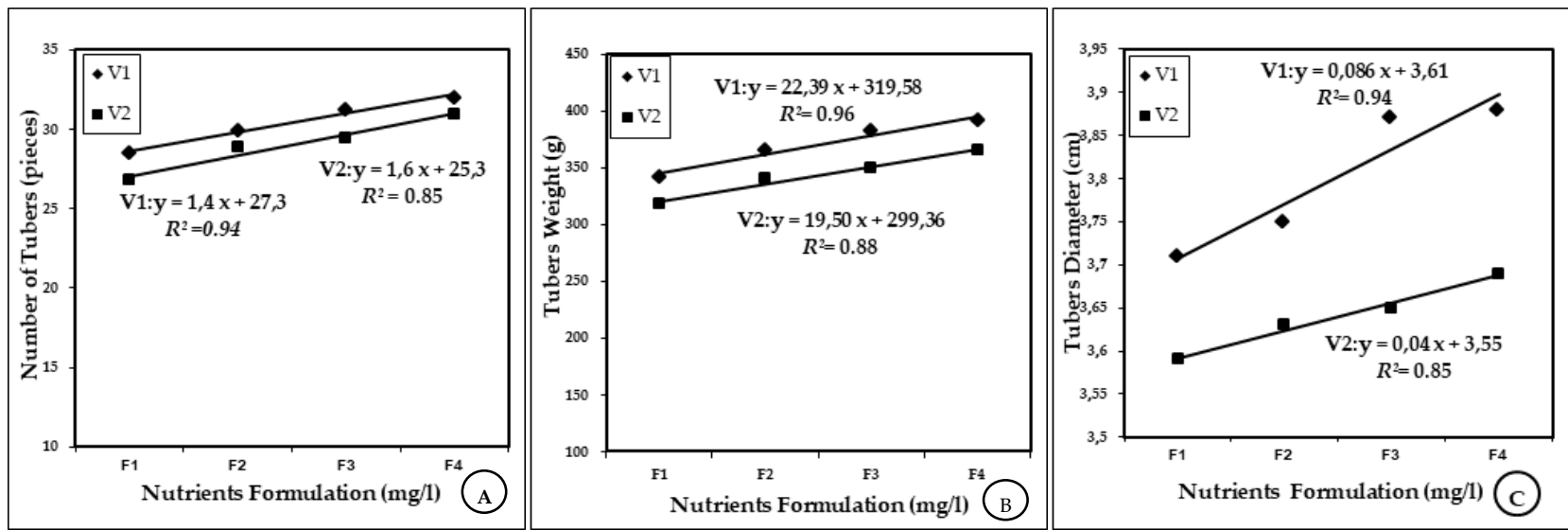

Fig. 2: The relationship of nutrients formulation with production parameters

\section{Tubers Quality}

Treatments on cultivar atlantic contributed to higher carbohydrate content of tubers than cultivar granola, while there was lower water content of tubers on cultivar granola than cultivar atlantic. Although cultivar atlantic had harder tubers, there was no significant difference with cultivar granola (Table 3). Treatment $\mathrm{F}_{4}$ had shown the highest carbohydrate content and tubers hardness, also it showed the lowest water content among four treatments, even though there was merely little difference with treatment $F_{2}$ and $F_{3}$. Figure 3 shows that nutrients had positive linear relationship with carbohydrate content of tubers, tubers hardness and water content of tubers on cultivar atlantic and granola, the equation of each parameter is shown on figure 3 (A, B and C).

Table 3: Carbohydrate Content, Tubers Hardness, and Water Content of Tubers on Nutrients Formultion

\begin{tabular}{|c|c|c|c|}
\hline Treatments & $\begin{array}{c}\text { Carbohydrate } \\
\text { Content (g/100g) }\end{array}$ & $\begin{array}{c}\text { Tubers } \\
\text { Hardness (Psi) }\end{array}$ & $\begin{array}{c}\text { Water } \\
\text { Content (\%) }\end{array}$ \\
\hline Cultivar & & & \\
\hline$V_{1}$ & $19.81^{\mathrm{b}}$ & 3.41 & $74.25^{\mathrm{b}}$ \\
\hline $\mathrm{V}_{2}$ & $18.27^{\mathrm{a}}$ & 3.39 & $75.29^{\mathrm{a}}$ \\
\hline Nutrients Formulation & & & \\
\hline F1 & $18.41^{\mathrm{b}}$ & $3.38^{\mathrm{b}}$ & $76.27^{\mathrm{b}}$ \\
\hline F2 & $19.03^{\mathrm{ab}}$ & $3.40^{\mathrm{a}}$ & $75.45^{\mathrm{ab}}$ \\
\hline F4 & $19.79^{\mathrm{a}}$ & $3.41^{\mathrm{a}}$ & $74.50^{\mathrm{a}}$ \\
\hline
\end{tabular}

Note: Values followed by the same letter indicated not significantly different according to LSD test at $5 \%$ test level.
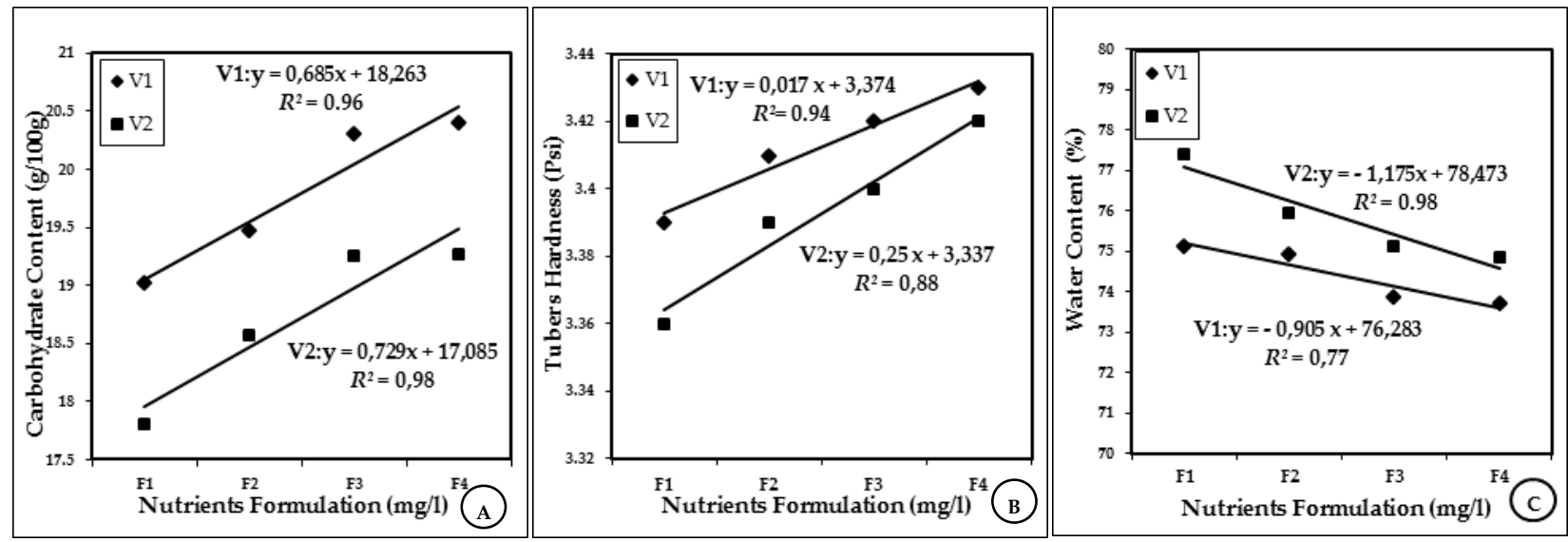

Fig. 3: The relationship of nutrients formulation with tuber quality parameters

\section{The Correlation Between Production Parameters and Quality Parameters of Potato Minitubers on Nutrients Formulations}

Table 4 shows the significant correlation between production parametes and tubers quality parameters. It shows that the increase of parameter of production stimulated better production of quality potato minituber. As it shows, there was a positive linear relationship between the number of tubers and tubers weight $(r=0.979)$, tubers diameter $(r=0.833)$, carbohydrate content $(r=0.931)$, tubers hardness $(r=0.989)$. In addition, Carbohydrate content of tubers had a positive linear relationship with tubers hardness $(r=0.930)$, although it had negative linear relationship with water content of tubers $(r=-0.938)$, the equation of each parameter is shown on figure 2 and 3 .

Table 4. Correlation Matrix between Production and Quality Parameters of Potato Minitubers on Nutrients Formulation

\begin{tabular}{|c|c|c|c|c|c|c|}
\hline Parameters & NT & TW & TD & CC & TH & WC \\
\hline NT & 1 & $0.979^{* *}$ & $0.833^{*}$ & $0.931^{* *}$ & $0.989^{* *}$ & $-0.935^{* *}$ \\
\hline TW & & 1 & $0.918^{* *}$ & $0.971^{* *}$ & $0.970^{* *}$ & $-0.959^{* *}$ \\
\hline TD & & & 1 & $0.939^{* *}$ & $0.812^{* *}$ & $-0.915^{*}$ \\
\hline CC & & & & 1 & $0.930^{* *}$ & $-0.981^{* *}$ \\
\hline TH & & & & & 1 & $-0.938^{* *}$ \\
\hline WC & & & & & & \\
\hline
\end{tabular}

Note: *significant, **highly significant, NT: Number of Tubers, TW: Tubers Weight, TD: Tubers Diameter, CC: Carbohydrate Content, TH: Tubers Hardness, WC: Water Content 


\section{DISCUSSION}

The treatments on atlantic cultivar resulted in heavier tubers weight and larger size of tubers compared to granola cultivar (Table 2), this related to the type of growth of both cultivars due to the differences in the genotype. Cultivar atlantic is one of superior cultivar which has pervasive root system as opposed to cultivar granola root system which is more collective, therefore cultivar atlantic could absorb more nutrients and oxygen around the root to produce energy for stimulating metabolic processes which contributed to growth and productivity of crop [8],[12],[22]. The effect of nutrients on crop growth depends up on the on concentration of nutrients [23], and also type of cultivars [24]. The research by [25] showed that the effect of nutrients on growth of potato crops depended on concentrate of nutrients and type of crops. Likewise, [24] reported that each potato cultivar required different optimum dose of nutrients. [26] reported that aeroponic system produced approximately 32.5-36.0 minitubers per crop and the production of the system was determined by potato cultivars.

The treatment $F_{4}$ produced more number of tubers per crop, heavier tubers weight per plant, and bigger tubers diameter than treatment $F_{1}$, however it was not significantly different from treatment $\mathrm{F}_{2}$ and $\mathrm{F}_{3}$. Number of tubers, tubers weight and tubers diameter were determined by metabolic activities taken place in plant tissue, such as photosynthesis, respiration and assimilate translocation. The net result of photosynthesis could be the number of tubers, tubers weight and tubers diameter. The number of tubers and tubers weight of potato, an organ of assimilate storage, was affected by the amount of assimilate which was translocated from source (leaves) to sink (tubers).

Assimilate accumulation from the output of photosynthesis produced glucose turning into fructose or sucrose, then it was translocated to the cells and polymerized to form carbohydrate [27],[28], afterwards the potato tubers were formed [4],[29], implicating to the number of tubers, tubers weight and tubers diameter.

Proportion and sufficiency of macronutrient $(\mathrm{N}, \mathrm{P}, \mathrm{K}, \mathrm{Ca}, \mathrm{Mg}$ and $\mathrm{S})$ and micronutrient $(\mathrm{Fe}, \mathrm{Cu}, \mathrm{Mo}, \mathrm{Zn}$ and $\mathrm{B})$ in formulation of aeroponic system was very important to support the process of plant physiology and increase tubers production and quality [29],[30]. The role of macronutrients in aeroponic system were: Nitrogen $(\mathrm{N})$ was necessary to synthesize chlorophyll for photosynthesis process [29],[30]. Phosphorus (P) was a component of phosphorilated nucleotide involved in the metabolic processes which required energy to absorb nutrients [11],[30],[31]. Potassium (K) was used to control physiological processes, such as turgor pressure, stomatal opening and closing and controlling carbohydrate translocation [32]. Besides, it could also be enzyme activator for photosynthesis and respiration. Calcium $(\mathrm{Ca})$ played a role in microflora growth in nutrients solution. Magnesium $(\mathrm{Mg})$ was the core of chlorophyll which formed adenosine diphosphat (ADP), adenosine triphosphate (ATP) and organic acids which were important for enzymatic reactions. Sulphur (S) was necessary for respiration and breakdown of fatty acids [27],[34].

The increase of carbohydrate content of tubers, tubers weight and the decrease of water content of tubers on cultivar atlantic and granola because of treatment $\mathrm{F}_{4}$ was related to the macronutrient and micronutrient in nutrients formulation of aeroponic system (Table 3). Function of the micronutrients were: Iron (Fe) was used to support enzyme catalase and peroxidase which catalyzed the breakdown of $\mathrm{H}_{2} \mathrm{O}_{2}$ into $\mathrm{H}_{2} \mathrm{O}$ and $\mathrm{O}_{2}$ [27],[35]. Cuprum (Cu) was useful to help electron transport system in photosynthesis process, carbohydraye metabolism, protein metabolism and nitrogen fixation [33]. Molybdenum (Mo) was used to help nitrate reductase that reduce nitrate to nitrite [27],[36]. Manganese (Mn) was the important component which helped formation of chlorophyll in oxidation-reduction reaction and in photosynthesis electron transport system [34],[37]. Zinc (Zn) was necessary in synthesis of triptophan amino acids and the formation of IAA hormone [36],[37]. Boron (B) was used to control transport of sugar and the formation of polysaccharide [33], [34].

The significant increase of carbohydrate content on treatment $\mathrm{F}_{4}$ was related to the increase of carbohydrate metabolic process which produced starch, pectin, hemicellulose and cellulose [33],[38]. According to [39], nutrient content of tubers could be changed depending on some factors, such as cultivars, types and compotition of fertilizer, tubers age and storage temperature. Moreover, tubers hardness was also related to the carbohydrate content of tubers because carbohydrate formed cell wall composed of cellulose, pectin, hemicellulose and polysaccharides for providing support to cell in tubers [34],[38]. Moreover, Potassium was necessary to affect the balance of nitrogen and phosphorus. The balance of nitrogen, phosphorus and potassium would increase tissue hardness and resistance against diseases [27],[34]. Furthermore, Water content of tubers was related to the accumulation of dry matter in the tubers determined by the number of assimilate available [4],[28].

According to [40], aside from light intensity, nutrients availability was also a factor which was crucial for process of plant physiology (photosynthesis, respiration and another metabolism), affecting balance of source (leaves) and sink (tubers). The high carbohydrate content in the tubers with treatment $\mathrm{F}_{4}$ implicated to the low water content of tubers related to the production of dry matter.

\section{CONCLUSIONS}

The treatment $\mathrm{F}_{4}$ gives the best effect on increasing production (number of tubers per plant, tubers weight, and tubers diameter) and quality tubers (carbohydrate content of tubers, tubers hardness and water content of tubers), although there is no significant difference compared to treatment $F_{2}$ and $F_{3}$. Applying treatments on cultivar atlantic can increase tubers weight, tubers diameter and carbohydrate content of tubers, while treatments on cultivar granola can reduce water content of tubers

\section{ACKNOWLEDGEMENTS}

We gratefully acknowledge the financial support of the Directorate of Research and Community Service, the Directorate General of strengthening research and development, Ministry of strengthening research, technology and higher education of The Republic of Indonesia so that this research can be accomplished.

\section{REFERENCES}

[1] FAO., 2010. Strengthening potato value chains: Technical and policy option for developing coutries. Food and Agriculture Organisation of the United Nation, Rome.

[2] Saravia, D., Farfan-Vignolo E.R., Gutierrez., De Mendiburu F., Schafleitner R., Bonierbale and M.A. Khan, 2016. Yield and physiological response of potatoes indicate different strategies to cope with drought stress and nitrogen fertilization. Am. J. Pot. Res., 93:288-295.

[3] Wattimena., 2005. Mikropropagation as an Alternatif technology for potatoes production in Indonesia. Thesis. Univ. Wisconsin, Madison. 203 p.

[4] Muhibuddin, A., S. Salam., Z. Razak and J. Boling, 2017. The Yield Response and Quality of Potato as Aeroponics Technology Results towards Methanol and Gliricidia sepium Leaf Extract in Medium Plain, J. Adv. Env. Biol.. 11(1): 1-9.

[5] Sub.Y.S., 2005. Experience of producing potato seeds G0 through aeroponics system. Korea International Cooporation Agency (KOICA). Korea.

[6] Nugaliyadde, M.M, Silva, H.D.M.D, Perera, R, Ariyaratna, D and U.K. Sangakkara, 2005. An aeroponic system for the production of the pre-basic seeds of potato, Ann. Srilanka Dep. Agri., vol. 7, pp. 199-208.

[7] Ress, H. M., 2004. Hydroponic Food Production.Woodridge Press, Santa Barbara, California.

[8] Chang D.C.,Park C.S., Kim S.Y., and Y.B Lee, 2012. Growth and tuberization of hydroponically grown potatoes. Am. J. Pot. Res., 55: 69-81.

[9] Ritter E., Angulo P., Riga P., Herrán C., Relloso J., and M. San-Jose, 2001. Comparison of hydroponic and aeroponic systems for the production of potato minitubers. Pot. Res., 44: 127-135.

[10] Nichols, M.A., 2005. Aeroponics and potatoes. Proceeding of the first international symposium on root and tuber crops 'Food Down Under'. Leiden. Netherlands. Int. Soc. Hort. Sci. (ISHS). pp 201-206.

[11] Farran I., and A.M. Mingo-Castel, 2006. Potato minituber production using aeroponics: Effects of density and harvesting intervals. Am. J. Pot. Res., 83(1): 47-53.

[12] Mateus-Rodriguez J.R., de Haan S., Andrade-Piedra J.L., Maldonado L., Hareau G., Barker I., Chuquillanqui C., Otazú V., Frisancho R., Bastos C., Pereira A.S., Medeiros C.A., Montesdeoca F., and J. Benítez, 2013: Technical and economic analysis of aeroponics and other systems for potato mini-tuber production in Latin America. Am. J. Pot. Res., 90: 357-368. 
[13] Howard, R., 2005. Hydroponic Questions and Answers for Succesful Growing. Santa Barbara, California: Woodbridge Press Publishing Company.

[14] Jensen, M. H. and W. L. Collins, 2005. Hydroponic vegetable production. Horticultural Reviews 7: 483-558.

[15] Caponetti, J. D., D. J. Gray., and R.. N. Trigiano, 2005. History of plant tissue and cell culture. P. 9 - 15. In R. N. Trigiano and D. J. Gray (eds). Plant development and biotechnology. CRC Press. LLC, 2000 New York.

[16] Chang, DC, Park, CS, Kim, SY Kim, SJ and Y.B. Lee, 2008. Physiological growth responses by nutrient interruption in aeroponically grown potatoes. Am. J. Pot. Res., vol. 85 pp. 15-23.

[17] Muhibuddin, A., Z. Razak, A. Halik and J. Boling, 2015. Growth and production of two varieties of potatoes in plains medium with methanol supplements. Int. J. Cur. Res. Aca. Rev., 3(5): 330-340.

[18] Madeiros, C. A. B., A. H. Ziemir., S. Daniel, and J. Pareira, 2002. Tuber Initiation in Hydro-ponically Grown Potatoes by Alteration of Solution pH. Hort. Science, 29 (6): 621-623.

[19] Rolot, J. L., H. Seutin, and D. Michelante, 2002. Potato minituber production thr.ough hydroponic: Assessment of a system combining the NFT and Gravel culture techniques for two types of nutrient solution. Am. J. Pot. Res.,. 27: 257-262.

[20] Lung'aho C. Nyongesa M, Mbiyu M.W, Ng'ang'a. N.M, Kipkoech D.N, Pwaipwai and P.J.Karinga, 2010. Potato (Solanum tuberosum) minituber production using aeroponics: another arrow in the quiver. In: Proceedings of the 12th biennial conference of the Kenya Agricultural Research Institut.

[21] Otazu, V., 2010. Manual on quality seed potato production using aeroponics. International Potato Centre (CIP). Lima, Peru. 2010; 44 retrived January 24th 2012, from http://cipotato. org/resources/publications/manual-on-quality-seedpotatoproduction-using-aeroponics.

[22] Chang, DC, Park, CS, Kim, SY Kim, SJ and Y.B Lee, 2008. Physiological growth responses by nutrient interruption in aeroponically grown potatoes. Am. J. Pot. Res., vol. 85 pp. 15-23.

[23] Mueller, D. S., Li, S., Hartman, G. L., and W. L. Pedersen, 2002. Use of aeroponic cham-bers and grafting to study partial resistance to fusarium solani f. sp. glycines in soybean. Department of Crop Science, University of Illionois, Urbana. Plant. Dis. 86: 1223 -1226.

[24] Love, S.L, Stark, J.C. and T. Salaiz, 2005. Response of four potato cultivars to rate and timing of nitrogen fertilizer, Am. J. Pot. Res., vol. 82, pp. 21-30.

[25] Goenadi, D. H. and I. Mariska. 1994. Shoot Initiation and Growth Enhancement by Humic Acids in Tissue Culture of Some Crop Species. Plant Cell Rep. In-press.

[26] Rykaczewska, K., 2016. The potato minituber production from microtubers in aeroponic culture. Plant Soil Environ., 5: $210-214$.

[27] Gardner, F. P., R .B. Pearce, dan R.L. Mitchell, 1991. Physiology of crop plant. Iowa State Univ. Press, USA.

[28] Muhibuddin, A., Z. Razak,S. Salam and J. Boling, 2016. Development of potato plants as the results of Aeroponic Technology by treating of methanol in plain medium at ulu ere sub district, Bantaeng Regency, South Sulawesi, Indonesia. Int. J. Cur. Res. Acad. Rev., 4(9): 140-348.

[29] Levy D, Coleman WK and R.E. Veileux, 2013. Adaptation of potato to water shortage: Irrigation management and enhancement of tolerance to drought and salinity. Am. J. Pot. Res., 90:186-206.

[30] He, M., and F.A. Dijkstra, 2014. Drought effect on plant nitrogen and phosphorus: a meta-analysis, New Phytologist 204: 924-931.

[31] Goins, G.D., Yorio, N.C., and R.M. Wheeler, 2004. Influence of nitrogen nutrition management on biomass partitioning and nitrogen use efficiency indices in hydroponically grown potato. J. Am. Soc. Hortic., Sci. 129.

[32] Molders K, Quinet M, Decat J, Secco B, Duiliere E, Pieters S, Kooii TV, Lutts S and D.V.D Straeten, 2012. Selection and hydroponic growth of potato cultivars for bioregenerative life support system. Adv. in Space Res., 50:156-165.

[33] Zakaria, B., 2010. Stimulants $\mathrm{CO}_{2}$ on photosynthesis and plant stress. Publisher Kretakufa Print, Makassar. ISBN: 9786029687309, Pages:169.

[34] Salisbury, F.B. and C. W. Ross, 1995. Plant Physiology. Wadsworth Publishing Co. New York.

[35] Wheeler, R.M., Mackowiak, C.L., Sager, J.C., Knott, W.M. and C.R. Hinkle, 2008. Potato growth and yield using Nutrient Film Technique (NFT). Am. J.Pot. Res., 67,p.177-187.

[36] Hussain, A., M. S. Awan, S. Ali, S.W. Khan, F. Morari and S. Ali, 2016. Spatial variability of soil micronutrients (Cu, Fe, Zn \& Mn) and population dynamic of mycoflora in potato fields of cknp region gilgit-baltistan pakistan. Pak. J. Agri. Sci., 53(3):541-550.

[37] Tan, L.P., He J., and S.K., Lee, 2003. Effects of root-zone temperatur on the root development and nutrient uptake of Lactuca sativa L"Panama" Grown in an aeroponic system in The Tropics, J. Plant Nutr., 25: 297-314.

[38] Salunkhe, D. K. and B. B. Desai, 1984. Postharvest biotechnology of vegetables, volume I, CRC Press Inc. Boca Raton Florida. p. 83-100.

[39] Waraich, E. A., A. Rashid, Saifullah, M.Y. Asraf, and Ehsamullah, 2011. Role of mineral nutrition in alleviation of drought stress in plants. Aust. J. Crop Sci., 5: 764-777.

[40] Moorby, J., 1997. The physiology of growth and tuber yield. P.153-194. In. P. M. Harris (ed.) The Potato Crop: The scientic basis for improvement. Chapman and Hall, London. 